\title{
Further characteristics of proto-European Y chromosomes
}

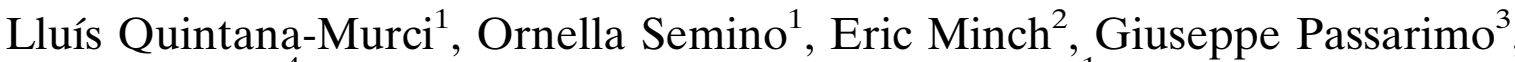 \\ Agnese Brega ${ }^{4}$ and A Silvana Santachiara-Benerecetti ${ }^{1}$ \\ ${ }^{1}$ Dipartimento di Genetica e Microbiologia, Università di Pavia, Pavia, Italy \\ ${ }^{2}$ Department of Genetics, Stanford University Medical Center, Stanford, USA \\ ${ }^{3}$ Dipartimento di Biologia Cellulare, Università della Calabria, Cosenza, Italy \\ ${ }^{4}$ Dipartimento di Biologia e Genetica per le Scienze Mediche, Università di Milano, Milano, Italy
}

\begin{abstract}
We examined a set of populations mainly from Europe but also from the Middle East and North Africa for the three Y-linked microsatellites YCAII, DYS19 (about 1300 individuals) and DYS392 (about 350 individuals). Three markers (YCAII a5-b1 Ht, DYS19-190 bp and DYS392-254 bp) show decreasing gradients of frequency from western Europe towards the Middle East which parallel that of the proto-European 49a,f/TaqI Ht 15. Indeed, a strong linkage disequilibrium between these markers and the 49a,f $\mathrm{Ht} 15$ is observed. We therefore suggest that the 49a,f/TaqI Ht 15, YCAII a5-b1 Ht, DYS19-190 bp and DYS392-254 bp Y chromosome could represent a component of the proto-European gene pool. This European specific compound haplotype distinctively characterises western Europeans and its very high incidence in these populations (particularly in the Basques) is discussed.
\end{abstract}

Keywords: proto-European Y chromosomes; European and Mediterranean populations; STR polymorphisms

The various components of the genetic structure of European populations have recently been debated in several papers. ${ }^{1-8}$ The authors argue the relative palaeolithic and neolithic genetic contribution to modern Europeans and the geographic pattern that would have resulted from the various migrations occurring in Europe at different times. These topics have been approached by analysis of both classical and uniparental-inherited markers. The principal component (PC) analysis of classical markers ${ }^{9-11}$ detected different population expansions associated with patterns of migrations of palaeolithic and neolithic peoples.

Correspondence: AS Santachiara-Benerecetti, Dipartimento di Genetica e Microbiologia, Università di Pavia, Via Abbiategrasso, 207, 27100 Pavia, Italy. Tel: (39) 0382 505542; Fax: (39) 0382 528496; E-mail: santa@ipvgen.unipv.it

Received 17 September 1998; revised 18 December 1998; accepted 10 February 1999
The mtDNA data, however, have given rise to disagreement on the importance of the different contributions to the European gene pool. ${ }^{3,5-7}$ Recently Torroni $e t a l^{8}$ described a pre-neolithic Europeanspecific mtDNA marker, the haplogroup $\mathrm{V}$, whose homeland is most likely the northern Iberian peninsula/ southern France. From this area, together with the older associated haplogroup $\mathrm{H}$ of Middle Eastern origin, it would have spread northeastward across Europe according to the second component of the classical markers PC analysis. ${ }^{10}$ Thus, these pre-neolithic haplogroups would have substantially contributed to the current central and northern European maternal gene pool.

As to $\mathrm{Y}$ chromosome data, in addition to a neolithic component revealed by the $12 \mathrm{f} 2 / \mathrm{Taq} \mathrm{I}-8 \mathrm{~kb}$ allele (with maximum values in the Middle East and a decreasing frequency gradient towards western Europe), they 
highlighted an important proto-European component in European populations indicated by the Y-49a,f/TaqI haplotype $(\mathrm{Ht}) 15^{2}$ This European-specific haplotype displays a gradient of frequencies opposite to that shown by the neolithic $12 \mathrm{f} 2-8 \mathrm{~kb}$ allele and maximum frequencies in peoples of western Europe, particularly in the Basques. ${ }^{2}$ It is of interest to note that, based on anthropological, linguistic and archaeological evidence, this population is thought to be a relic of ancient palaeolithic and/or mesolithic European populations. $^{10,12,13}$

The different relative contribution of the two sexes to the European gene geography has also been a matter of debate and, as Cavalli-Sforza and $\mathrm{Minch}^{3}$ and Richards et $a l^{5}$ have pointed out, further information on malemediated genetic variation in Europe would be helpful at this stage. We have therefore examined a sample of the previously studied populations ${ }^{2}$ for three Y-linked microsatellites in order better to identify the European male-specific features. More than 1300 individuals were analysed for the dinucleotide system YCAII $^{14}$ and the tetranucleotide DYS19, ${ }^{15}$ and about 350 individuals for the trinucleotide DYS392, ${ }^{16}$ following procedures reported by the authors who first described these polymorphisms. ${ }^{14-16}$

Three markers, the YCAII a5-b1 haplotype, the DYS19-190 bp allele and the DYS392-254 bp allele, have turned out to be very useful. Table 1 shows their frequencies in the Europeans examined and in some other populations of interest. Table 1 and the maps of the interpolated frequencies (Figure $1 \mathrm{~A}-\mathrm{C}$ ) present all three markers showing their maximum values in peoples of western Europe and a decreasing gradient of frequencies from western to southeastern European populations. The only exceptions to the observed gradients are the unexpectedly high frequencies of YCAII Ht a5-b1 in Hungary (Figure 1A) and the DYS19-190 bp allele in the Middle East (Figure 1B), which are most probably due to recurrent mutations, as also indicated by their being in a different $Y$ haplotype background in these areas (Passarino, G. personal communication 1998).

It is worth noting that, with the above exceptions, the observed gradients parallel well the distribution (Figure 1D) of the more stable ${ }^{2,26}$ (Santachiara-Benerecetti A.S., unpublished data 1998) proto-European 49a,f Ht $15 .^{2}$ Indeed, a strong linkage disequilibrium between the 49a,f Ht 15 and the three Y microsatellite markers is observed: $81 \%$ of the 202 chromosomes $49 \mathrm{a}$,f Ht 15 typed for the YCAII were a5-b1, 89\% of the 191 typed for the DYS19 were $190 \mathrm{bp}$, and $72 \%$ out of the 177 typed for both systems showed the association of the three Y markers. As to the DYS392 STR, 79\% out of the 28 chromosomes $49 \mathrm{a}, \mathrm{f} \mathrm{Ht} 15$ typed for this microsatellite were $254 \mathrm{bp}$.

We attempted to estimate the age of the $\mathrm{Ht} 15 \mathrm{Y}$ chromosome variation by analysis of seven microsatellites (YCAIIa, YCAIIb, DYS19, DYS389-I, DYS390, DYS391 and DYS392) $)^{14-16}$ in $28 \mathrm{Ht} 15 \mathrm{Y}$ chromosomes, following the methods of Bertranpetit and Calafell, ${ }^{27}$ and Goldstein et al, ${ }^{28}$ assuming generation spans of 20 years and, for Goldstein's method, ${ }^{28}$ an effective population size of 5000 individuals. Different mutation rates $\left(1.2 \times 10^{-4}, 4.8 \times 10^{-4}, 1 \times 10^{-3}\right.$ and $\left.2.1 \times 10^{-3}\right)^{29-31}$ were used, and coalescence times of $58666,14668,7040$ and 3352 years (first method), and $51080,24800,11186$ and 5173 years (second method) were obtained. However, the highest mutation rate $\left(2.1 \times 10^{-3}\right)$ we used, which gives the most critical values in this context, produces some discrepancies. Although it should provide valid information on up to 40000 to 50000 years, ${ }^{31}$ it gave a period for the preColumbian peopling of the Americas of 2147 BP years which is clearly an underestimate. ${ }^{32}$

Even though such uncertainty in the mutation rates does not allow us to assess safely the date of the origin of the $\mathrm{Ht} 15$ variation, other evidence strongly supports an ancient origin of this haplotype. Its geographic distribution appears to be similar to that of other markers, such as the synthetic map of Europe based on the fifth principal component from nuclear data, ${ }^{10}$ the pre-neolithic mtDNA haplogroup $\mathrm{V},{ }^{8}$ and the cystic fibrosis $\Delta$ F-508 allele, ${ }^{10,33,34}$ which, it has been suggested precede the spread of agriculture in Europe.

These reasons lead us to consider, therefore, the European 49a,f Ht 15, YCAII a5-b1, DYS19-190 bp and DYS392-254 bp Y chromosome compound haplotype as a most likely component of an ancient proto-European gene pool. It distinctively characterises the populations of western Europe where it presumably originated and where the neolithic people arrived later (6-7000 years ago $)^{10,35}$. Its very high incidence in these populations (particularly in the Basques) and its low level of genetic diversity most likely resulted from genetic drift which occurred during the last glacial period, when population sizes were small, and from subsequent population expansion at the end of that period when climatic conditions became more favourable. Basques, in their longer isolation, appear to have compounded the original genetic idiosyncrasies of western Europeans. 
Table 1 Frequencies in percentage of the YCAII a5-b1 haplotype, DYS19-190 bp allele and DYS392-254 bp allele in different populations

\begin{tabular}{|c|c|c|c|c|c|c|c|c|}
\hline \multirow[b]{2}{*}{ Population } & \multirow[b]{2}{*}{ Geographic location } & \multicolumn{2}{|c|}{ YCAII a5-b1 Ht } & \multicolumn{2}{|c|}{ DYS19-190 bp } & \multicolumn{2}{|c|}{ DYS392-254 bp } & \multirow[b]{2}{*}{ Ref. } \\
\hline & & No. & $\%$ & No. & $\%$ & No. & $\%$ & \\
\hline Spanish Basque & $43^{\circ} 15^{\prime} \mathrm{N}, 2^{\circ} 56^{\prime} \mathrm{W}$ & 48 & 81.3 & 52 & 78.8 & - & - & present study \\
\hline French Basque & $43^{\circ} 30^{\prime} \mathrm{N}, 1^{\circ} 30^{\prime} \mathrm{W}$ & 43 & 74.4 & 42 & 83.3 & - & - & present study \\
\hline Béarnais & $43^{\circ} 30^{\prime} \mathrm{N}, 1^{\circ} 00^{\prime} \mathrm{W}$ & 27 & 70.4 & 24 & 75.0 & - & - & present study \\
\hline Basque 2 & $43^{\circ} 15^{\prime} \mathrm{N}, 2^{\circ} 56^{\prime} \mathrm{W}$ & - & - & 52 & 78.9 & 52 & 75.0 & 17 \\
\hline Catalan & $41^{\circ} 25^{\prime} \mathrm{N}, 2^{\circ} 10^{\prime} \mathrm{E}$ & 32 & 59.4 & 26 & 69.2 & - & - & present study \\
\hline Catalan 2 & $41^{\circ} 25^{\prime} \mathrm{N}, 2^{\circ} 10^{\prime} \mathrm{E}$ & - & - & 25 & 80.0 & 32 & 37.5 & 17 \\
\hline Andalusian & $37^{\circ} 00^{\prime} \mathrm{N}, 3^{\circ} 30^{\prime} \mathrm{W}$ & 55 & 49.1 & 48 & 62.5 & 30 & 53.3 & present study \\
\hline Dutch & $52^{\circ} 30^{\prime} \mathrm{N}, 4^{\circ} 50^{\prime} \mathrm{E}$ & 23 & 65.2 & 29 & 58.6 & - & - & present study \\
\hline Dutch 2 & $52^{\circ} 30^{\prime} \mathrm{N}, 4^{\circ} 50^{\prime} \mathrm{E}$ & - & - & - & - & 88 & 54.0 & 18 \\
\hline British & $51^{\circ} 30^{\prime} \mathrm{N}, 0^{\circ} 10^{\prime} \mathrm{W}$ & 19 & 63.2 & 60 & 70.0 & - & - & 19,20 \\
\hline Finnish & $60^{\circ} 10^{\prime} \mathrm{N}, 24^{\circ} 58^{\prime} \mathrm{E}$ & - & - & - & - & 280 & 6.1 & 21 \\
\hline German & $50^{\circ} 00^{\prime} \mathrm{N}, 10^{\circ} 00^{\prime} \mathrm{E}$ & - & - & 306 & 44.0 & - & - & 19 \\
\hline Slovak & $48^{\circ} 06^{\prime} \mathrm{N}, 17^{\circ} 00^{\prime} \mathrm{E}$ & - & - & 81 & 21.0 & - & - & 19 \\
\hline German (Berlin) & $52^{\circ} 20^{\prime} \mathrm{N}, 13^{\circ} 00^{\prime} \mathrm{E}$ & 77 & 48.0 & 233 & 39.0 & 70 & 26.0 & 18 \\
\hline Swiss (Berne) & $46^{\circ} 57^{\prime} \mathrm{N}, 7^{\circ} 30^{\prime} \mathrm{E}$ & - & - & 100 & 56.0 & 64 & 39.0 & 18 \\
\hline Hungarian & $47^{\circ} 30^{\prime} \mathrm{N}, 19^{\circ} 05^{\prime} \mathrm{E}$ & 53 & 69.8 & 52 & 44.2 & 30 & 20.0 & present study \\
\hline North Italian & $45^{\circ} 28^{\prime} \mathrm{N}, 9^{\circ} 12^{\prime} \mathrm{E}$ & 35 & 45.7 & 64 & 54.7 & - & - & present study \\
\hline Central Italian & $43^{\circ} 20^{\prime} \mathrm{N}, 10^{\circ} 50^{\prime} \mathrm{E}$ & 113 & 38.0 & 89 & 55.1 & - & - & present study \\
\hline Sardinian & $40^{\circ} 30^{\prime} \mathrm{N}, 9^{\circ} 00^{\prime} \mathrm{E}$ & 133 & 12.8 & 239 & 27.2 & 27 & 22.2 & present study \\
\hline Roman & $41^{\circ} 53^{\prime} \mathrm{N}, 12^{\circ} 30^{\prime} \mathrm{E}$ & - & - & - & - & 100 & 26.0 & 18 \\
\hline Calabrian & $39^{\circ} 20^{\prime} \mathrm{N}, 15^{\circ} 39^{\prime} \mathrm{E}$ & 70 & 32.9 & 105 & 47.6 & 29 & 20.7 & present study \\
\hline Apulian & $40^{\circ} 20^{\prime} \mathrm{N}, 16^{\circ} 52^{\prime} \mathrm{E}$ & 67 & 35.8 & 83 & 39.8 & - & - & present study \\
\hline Sicilian & $37^{\circ} 20^{\prime} \mathrm{N}, 14^{\circ} 00^{\prime} \mathrm{E}$ & 47 & 36.2 & 55 & 50.9 & 32 & 46.9 & present study \\
\hline Albanian & $41^{\circ} 20^{\prime} \mathrm{N}, 19^{\circ} 49^{\prime} \mathrm{E}$ & 40 & 27.5 & 40 & 40.0 & - & - & present study \\
\hline Greek & $38^{\circ} 00^{\prime} \mathrm{N}, 23^{\circ} 44^{\prime} \mathrm{E}$ & 87 & 26.4 & 42 & 28.6 & 30 & 23.3 & present study \\
\hline Adygei & $48^{\circ} 00^{\prime} \mathrm{N}, 34^{\circ} 00^{\prime} \mathrm{E}$ & 21 & 19.0 & 20 & 25.0 & - & - & present study \\
\hline Georgian & $42^{\circ} 30^{\prime} \mathrm{N}, 45^{\circ} 00^{\prime} \mathrm{E}$ & 64 & 15.6 & 55 & 41.8 & 30 & 10.0 & present study \\
\hline Turkish & $37^{\circ} 51^{\prime} \mathrm{N}, 32^{\circ} 30^{\prime} \mathrm{E}$ & 84 & 20.2 & 43 & 39.5 & 36 & 16.7 & present study \\
\hline Sephardi Jewish ${ }^{\mathrm{a}}$ & $32^{\circ} 00^{\prime} \mathrm{N}, 35^{\circ} 00^{\prime} \mathrm{E}$ & 42 & 16.7 & 42 & 40.5 & - & - & present study \\
\hline Ashkenazi Jewish $^{\mathrm{a}}$ & $32^{\circ} 00^{\prime} \mathrm{N}, 35^{\circ} 00^{\prime} \mathrm{E}$ & 41 & 17.1 & 41 & 46.3 & 27 & 11.1 & present study \\
\hline Lebanese & $33^{\circ} 52^{\prime} \mathrm{N}, 35^{\circ} 30^{\prime} \mathrm{E}$ & 52 & 15.4 & 77 & 51.9 & 29 & 10.3 & present study \\
\hline Algerian & $36^{\circ} 50^{\prime} \mathrm{N}, 3^{\circ} 00^{\prime} \mathrm{E}$ & 35 & 2.9 & 38 & 23.7 & 14 & 7.1 & present study \\
\hline Tunisian & $36^{\circ} 50^{\prime} \mathrm{N}, 10^{\circ} 13^{\prime} \mathrm{E}$ & 64 & 4.7 & 72 & 41.7 & 42 & 7.1 & present study \\
\hline Egyptian & $30^{\circ} 03^{\prime} \mathrm{N}, 31^{\circ} 15^{\prime} \mathrm{E}$ & 44 & 6.8 & 44 & 36.4 & - & - & 20 \\
\hline
\end{tabular}

${ }^{\mathrm{a}}$ The individuals belonging to these two samples were collected in Tel Aviv and were mainly from Tunisia and Morocco (Sephardi) and from Poland and Russia (Ashkenazi). However, they were both located in Israel because of their Middle Eastern origin, as testified by autosomal and uniparental marker studies. ${ }^{22-25}$

At present, in comparison with mtDNA analysis, the Y chromosome seems to display, at least in Europe, a greater geographic clustering and more defined frequency clines. In any case, one must not forget that mtDNA and $\mathrm{Y}$ chromosome variations record two separate genetic histories of a population and supply information on related but different aspects of the same reality.
In conclusion, even though recurrent mutations have certainly occurred in STR variation, the three Y-linked microsatellites of this study turned out to be very informative. Indeed, each of them identifies geographic clines in Europe and gives evidence of old genetic characteristics which, in spite of subsequent migrations, still persist in European populations. Moreover, the results of this study find support in archaeological 
A

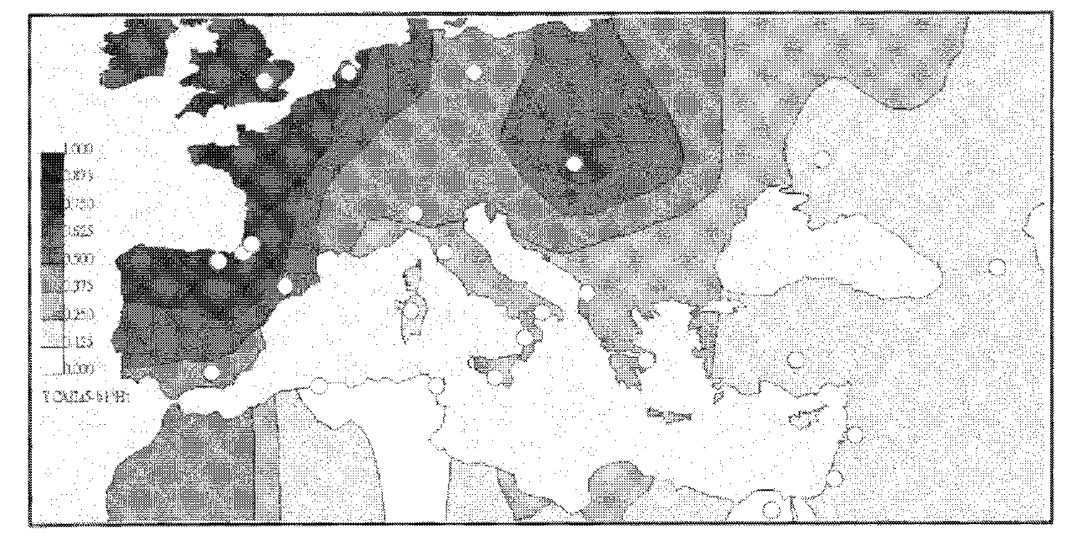

B

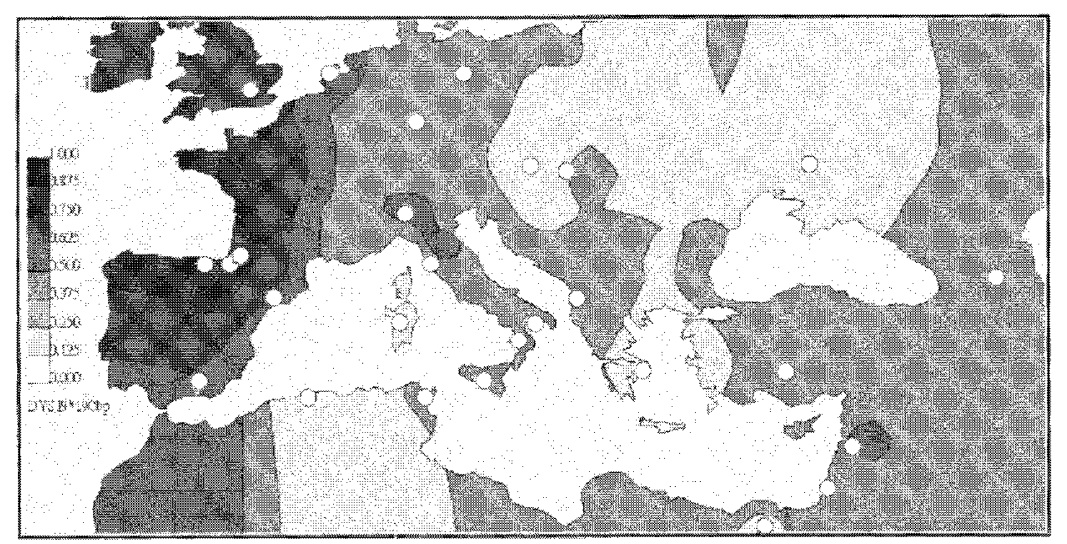

C

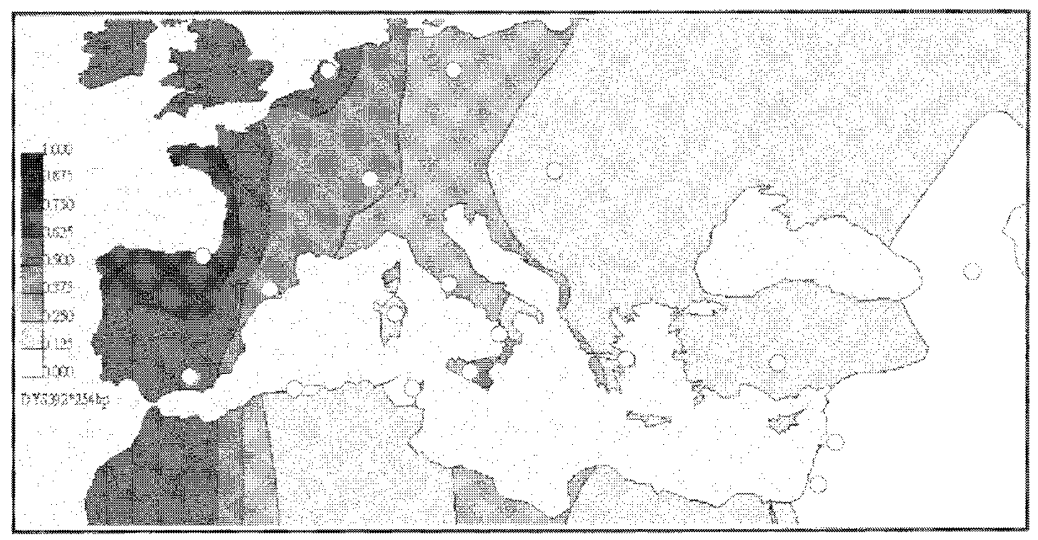

D



Figure 1 Maps of interpolated frequencies for A YCAII a5-b1 Ht; B DYS19-190 bp allele; C DYS392-254 bp allele and $\mathbf{D} 49$ a f/TaqI Ht $15^{2}$ Points were linearly interpolated by the Genography program on a grid with a resolution of $0.5^{\circ}$ latitude and $1.0^{\circ}$ longitude, using inverse square distance weighted values of Voronoi neighbours (Cavalli-Sforza et al, $p 46$ ). ${ }^{10}$ The circles indicate locations of data samples. (Finland is not represented on these maps.) 
observations which locate important cave art records from the early palaeolithic in southwestern France and northern Spain, ${ }^{10}$ corresponding with the Basque region.

\section{Acknowledgements}

We are grateful to all the colleagues who have provided us with population samples: J Bertranpetit, for Spanish Basques and Catalans; A Cambon-Thomsen for French Basques and Béarnais; J Garcia-Puche for Andalusians; J Béres for Hungarians; the AVIS centre of Volterra for central Italians; A Grasso and P Pignatelli for Apulians; M Maccioni and G Cossu for Sardinians; G Passarino for Calabrians, Albanians and Greeks; J Kidd and K Kidd for Adygei; I Nasidze for Georgians; M Fellous for Algerians and Tunisians; and $G$ Modiano for Ashkenazi and Sephardi Jews. We also thank A Arslan for help in collection of the Turkish samples. A Liu and $M$ van Gijn are also acknowledged for their help in some STR typing. This work has been supported by funds from the Ministry of University (MURST ex 40\%) awarded to ASS-B and $\mathrm{AB}$ and the CNR PF 'Beni Culturali' to ASS-B; LQ-M is a Marie Curie Fellow of the EC (ERBFMBICT-961830).

\section{References}

1 Richards M, Côrte-Real H, Forster P et al: Paleolithic and neolithic lineages in the European mitochondrial gene pool. Am J Hum Genet 1996; 59: 185-203.

2 Semino O, Passarino G, Brega A, Fellous M, SantachiaraBenerecetti AS: A view of the neolithic demic diffusion in Europe through two Y chromosome-specific markers. Am J Hum Genet 1996; 59: 964-968.

3 Cavalli-Sforza LL, Minch E: Paleolithic and neolithic lineages in the European mitochondrial gene pool. Am J Hum Genet 1995; 61: 247-251.

4 Comas D, Calafell F, Mateu E, Pérez-Lezaun A, Bosch E, Bertranpetit J: Mitochondrial DNA variation and the origin of the Europeans. Hum Genet 1997; 99: 443-449.

5 Richards M, Macaulay V, Sykes B et al: Reply to CavalliSforza and Minch. Am J Hum Genet 1997; 61: 251-254.

6 Barbujani G, Bertorelle G, Chikhi L: Evidence for paleolithic and neolithic gene flow in Europe. Am J Hum Genet 1998; 62: 488-491.

7 Richards M, Sykes B: Reply to Barbujani et al. Am J Hum Genet 1998; 62: 491-492.

8 Torroni A, Bandelt HJ, D'Urbano L et al: MtDNA analysis reveals a major late paleolithic population expansion from southwestern to northwestern Europe. Am J Hum Genet 1998; 62: 1137-1152.

9 Menozzi P, Piazza A, Cavalli-Sforza LL: Synthetic maps of human gene frequencies in Europe. Science 1978; 201: 786-792.

10 Cavalli-Sforza LL, Menozzi P, Piazza A: The History and Geography of Human Genes Princeton University Press: Princeton, 1994.

11 Piazza A, Rendine S, Minch E, Menozzi P, Mountain J, Cavalli-Sforza LL: Genetics and the origin of European languages. Proc Natl Acad Sci USA 1995; 92: 5836-5840.

12 Aranzadi T: El pueblo Euskalduna, Diputacion de Guipuzcoa. San Sebastian, 1889.
13 Collins R: The Basques. Blackwell: Oxford, 1986.

14 Mathias N, Bayés M, Tyler-Smith C: Highly informative compound haplotypes for the human Y chromosome. Hum Mol Genet 1994; 3: 115-123.

15 Roewer L, Arnemann J, Spurr NK, Grzeschik KH, Epplen JT: Simple repeat sequences on the human Y chromosome are equally polymorphic as their autosomal counterparts. Hum Genet 1992; 89: 389-394.

16 Roewer L, Kayser M, Dieltjes $\mathrm{P}$ et al: Analysis of molecular variance (AMOVA) of Y-chromosome-specific microsatellites in two closely related human populations. Hum Mol Genet 1996; 5: 1029-1033.

17 Pérez-Lezaun A, Calafell F, Seielstad M et al: Population genetics of Y-chromosome short tandem repeats in humans. J Mol Evol 1997; 45: 265-270.

18 Kayser M, Caglià A, Corach D et al: Evaluation of Y-chromosomal STRs: a multicenter study. Int J Legal Med 1997; 110: 125-133.

19 Santos FR, Gerelsaikhan T, Munkhtuja B, Oyunsuren T, Epplen JT, Pena SDJ: Geographic differences in the allele frequencies of the human Y-linked tetranucleotide polymorphism DYS19. Hum Genet 1996; 97: 309-313.

20 Ciminelli BM, Pompei F, Malaspina P et al: Recurrent simple tandem repeat mutations during human Y-chromosome radiation in Caucasian subpopulations. $J$ Mol Evol 1995; 41: 966-973.

21 Kittles RA, Perola M, Peltonen L et al: Dual origin of Finns revealed by Y chromosome haplotype variation. $\mathrm{Am}$ J Hum Genet 1998; 62: 1171-1179.

22 Livshits G, Sokal RR, Kobyliansky E: Genetic affinities of Jewish populations. Am J Hum Genet 1991; 49: 131-146.

23 Ritte U, Neufeld E, Prager EM et al: Mitochondrial DNA affinity of several Jewish communities. Hum Biol 1993; 65: 359-385.

24 Ritte U, Neufeld E, Broit M, Shavit D, Motro U: The differences among Jewish communities - Maternal and Paternal contributions. J Mol Evol 1993; 37: 435-440.

25 Santachiara-Benerecetti AS, Semino O, Passarino G et al: The common, Near-Eastern origin of Ashkenazi and Sephardi Jews supported by Y-chromosome similarity. Ann Hum Genet 1993; 57: 55-64.

26 Persichetti F, Blasi P, Hammer M et al: Disequilibrium of multiple DNA markers on the human Y chromosome. Ann Hum Genet 1992; 56: 303-310.

27 Bertanpetit J, Calafell F: Genetic and geographical variability in cystic fibrosis: evolutionary considerations. In Chadwick DJ (ed). Variation in the Human Genome. Ciba Foundation Symposium 197. Wiley: New York, 1996.

28 Goldstein DB, Ruiz-Linares AR, Cavalli-Sforza LL, Feldman MW: Genetic absolute dating based on microsatellites and the origin of modern humans. Proc Natl Acad Sci USA 1995; 92: 6723-6727.

29 Cooper G, Amos W, Hoffman D, Rubinsztein DC: Network analysis of human Y microsatellite haplotypes. Hum Mol Genet 1996; 5: 1759-1766.

30 Heyer E, Puymirat J, Dieltjes P, Bakker E, de Knijff P: Estimating Y chromosome specific microsatellite mutation frequencies using deep rooting pedigrees. Hum $\mathrm{Mol}$ Genet 1997; 6: 799-803.

31 de Knijff $\mathrm{P}$, Kayser $\mathrm{M}$, Caglià A et al: Chromosome $\mathrm{Y}$ microsatellites: population genetic and evolutionary aspects. Int J Legal Med 1997; 110: 134-140. 
32 Underhill PA, Jin L, Zemans R et al: A pre-Columbian Y chromosome-specific transition and its implications for human evolutionary history. Proc Natl Acad Sci USA 1996; 93: 196-200.

33 Devoto M, Romeo G, Serre JL et al: Gradient of distribution in Europe of the world CF mutation and of its associated haplotypes. Hum Genet 1990; 85: 436-441.
34 Slatkin M, Rannala B: Estimating the age of alleles by use of intraallelic variability. Am J Hum Genet 1997; 60: 447-458.

35 Bertranpetit J, Cavalli-Sforza LL: A genetic reconstruction of the history of the population of the Iberian Peninsula. Ann Hum Genet 1991; 55: 51-67. 